CONCEIÇÃO, A.M. da; FORTES, G. R. de L.; SILVA, J.B. da. Influência do ácido acetilsalicílico, da sacarose e da temperatura na conservação in vitro de segmentos caulinares de batata Horticultura Brasileira, Brasília, v. 17, n. 3, p.182-185, novembro 1999.

\title{
Influência do ácido acetilsalicílico, da sacarose e da temperatura na con- servação in vitro de segmentos caulinares de batata.
}

\author{
Adriane M. da Conceição ${ }^{1}$; Gerson Renan de L. Fortes² ; João Baptista da Silva. ${ }^{3}$ \\ ${ }^{1 /}$ UFPel - Colegiado de Pós-Graduação em Agronomia, C. Postal 354, 96.010-900 Pelotas-RS; ${ }^{2 /}$ Embrapa Clima Temperado, C. Postal \\ 403, 96001-970 Pelotas-RS; ${ }^{3 /}$ UFPel/IFM, C.Postal 354, 96.010-900 Pelotas-RS.
}

\begin{abstract}
RESUMO
O presente trabalho foi realizado no Laboratório de Cultura de Tecidos da Embrapa Clima Temperado (Pelotas-RS), com o objetivo de estudar o efeito do ácido acetil salicílico (AAS), associado à sacarose e à temperatura na conservação in vitro de segmentos caulinares das cultivares de batata Baronesa e Santo Amor. Os segmentos foram inoculados em meio de cultura com sais e vitaminas de MS, acrescido de 100 mg.L. - $^{-1}$ de mio-inositol, 6 g.L.- ágar e com sacarose nas concentrações de 10,30 e 50 g.L. $\mathrm{L}^{-1}$ combinadas com ácido acetil salicílico a $0,3,6,9$ e $12 \mathrm{mg} . \mathrm{L}^{-1}$. Após a inoculação o material foi mantido às temperaturas de $10 \mathrm{e} 25^{\circ} \mathrm{C}$. O experimento constituiu-se de um fatorial $\mathrm{AxBxCxD}$ [temperatura (2) x sacarose (3) x AAS (5) x cultivar (2)], em blocos casualizados, com quatro repetições, sendo cada explante uma parcela. O comprimento do segmento caulinar foi analisado pelo teste de Duncan e pela regressão polinomial dos fatores. As avaliações foram iniciadas 15 dias após a instalação do experimento e continuadas a cada 15 dias, sucessivamente ao longo de 180 dias. Da variável percentagem de sobrevivência do material em conservação in vitro foi calculado apenas o valor médio. A concentração de sacarose de 30 g.L. $\mathrm{L}^{-1}$ no meio de cultura, e a temperatura de $10^{\circ} \mathrm{C}$, foram os melhores tratamentos para a melhor conservação in vitro e maior percentagem de sobrevivência dos segmentos caulinares de batata.
\end{abstract}

Palavras chaves: Solanum tuberosum L., cultura de tecidos.

\section{ABSTRACT}

Effect of acetyl salycilic acid, sucrose and temperature on in vitro storage of potato shoots.

This work was carried out at the Tissue Culture Laboratory at Embrapa Clima Temperado Pelotas-RS, Brazil, to evaluate the influence of acetyl salycilic acid (ASA), sucrose and temperature in the in vitro storage of potato shoot cvs. Baronesa and Santo Amor. The shoot segments were inoculated on a medium containing MS salts, vitamins, myo-inositol (100 mg.L $\left.\mathrm{L}^{-1}\right)$, agar (6.0 g.L $\left.\mathrm{L}^{-1}\right)$ and sucrose at 10,30 and $50 \mathrm{~g} . \mathrm{L}^{-1}$ combined with acetyl salicylic acid at $0,3,6,9$ and $12 \mathrm{mg} . \mathrm{L}^{-1}$. After inoculation the material was kept at 10 or $25^{\circ} \mathrm{C}$. The experiment was designed in a factorial A x B x C x D [temperature (2) x sucrose (3) x ASA (5) x cultivars (2)] and displayed in a randomized block with four replicates being each explant one plot. The shoot growth was studied and the data were compared by the Duncan test and by polinomial regression. Evaluation took place every 15 days and the last one was done 180 days after inoculation. The best results were obtained using in vitro storage with the shoots kept at $10^{\circ} \mathrm{C}$, on a medium containing to $30 \mathrm{~g} . \mathrm{L}^{-1}$ sucrose.

Keywords: Solanum tuberosum L., tissue culture.

\section{(Aceito para publicação em 01 de setembro de 1999)}

\begin{abstract}
$\mathrm{A}_{\mathrm{a}}$ batata (Solanum tuberosum L.) é a olerácea mais importante cultivada no Brasil, pelo seu alto potencial de rendimento e pelas suas propriedades nutricionais, com produtividade média de 15 t/ha, com uma área plantada, em 1995 de 178.174 ha e uma produção de 2.692334 t (IBGE, 1997). As áreas de produção estão concentradas, principalmente no Centro-Sul do país; o Rio Grande do Sul encontra-se em primeiro lugar em área plantada e em quinto em produtividade, com 9,9 t/ha (IBGE, 1997).
\end{abstract}

O processo de conservação in vitro, que é baseado no crescimento lento das espécies, tem sido considerado uma al- ternativa à conservação de germoplasma feita a campo em espécies propagadas vegetativamente (Roca et al., 1991).

$\mathrm{O}$ crescimento rápido das espécies in vitro exige mais mão-de-obra e aumenta a possibilidade de perdas devido à contaminação do material durante repetições contínuas de subcultivo. Por outro lado, o processo de conservação in vitro diminui o número de subcultivos, como também reduz os custos financeiros, as contaminações por microorganismos e a variação somaclonal. O método de conservação in vitro objetiva desacelerar ou até suprimir totalmente o crescimento das células e tecidos in vitro, aumentando o período entre cada subcultivo (Dorion et al., 1991).

O crescimento lento tem sido um sucesso na manutenção das gemas de algumas espécies e tem manifestado aplicabilidade podendo ser utilizado rotineiramente para espécies como: batata, batata-doce, maçã, pêra, kiwi, banana, forrageiras e ornamentais (Withers \& Williams, 1990). Entre os fatores mais estudados para retardamento do crescimento, encontram-se a redução de temperatura, bem como adição de inibidores de crescimento e osmóticos ao meio de cultura.

Os retardantes de crescimento são um grupo de componentes sintéticos que 
reduzem o elongamento da haste; e, geralmente aumentam a coloração verde das folhas. Esses componentes inibem a divisão celular no meristema subapical das gemas, mas tem pouco efeito na produção de folhas e no crescimento de raízes (Gianfagna, 1987).

Segundo Salisbury (1992), o ácido acetil salicílico é um hormônio vegetal importante para algumas respostas fisiológicas conhecidas. Tais como, formação floral (Kaihara et al., 1981; Khurama \& Maheshwari, 1978); fechamento dos estômatos (LarqueSaavendra, 1979); inibição da síntese de etileno (Leslie \& Romani, 1988); resistência a patógenos (Mills \& Wood, 1984); produção de proteínas relacionadas a patogenicidade (Ohashi \& Matsuoka, 1987) e promotor na formação de colônias de protoplastos (Carswell et al., 1989).

Leite et al. (1995), conservaram meristemas de alho in vitro utilizando o ácido acetil salicílico em concentrações de até 4,0 mg. $\mathrm{L}^{-1}$ combinado com manitol 30 g.L.-1, em substituição a sacarose; a maior percentagem de plantas sobreviventes $(34,55 \%)$ foi obtida na concentração de $0,5 \mathrm{mg} . \mathrm{L}^{-1}$, de ácido acetilsalicílico.

Esse trabalho teve como objetivo estudar a modificação do meio de cultura, utilizando o ácido acetilsalicílico como retardante de crescimento associado a um agente osmótico, a sacarose, e à temperatura, na conservação in vitro de segmentos caulinares das cultivares de batata, Baronesa e Santo Amor.

\section{MATERIAL E MÉTODOS}

O trabalho foi realizado no Laboratório de Cultura de Tecidos da Embrapa Clima Temperado, Pelotas-RS.

Foram utilizadas plantas de batata (Solanum tuberosum L.) das cultivares Baronesa e Santo Amor. Os tubérculos dessas cultivares foram plantados em vasos contendo solo esterilizado com brometo de metila. Após o crescimento e desenvolvimento das ramas até a altura aproximada de $20-25 \mathrm{~cm}$, estas foram cortadas e utilizadas para retirada dos meristemas.

O meio de cultura utilizado para isolamento de meristemas foi constituído por sais e vitaminas de MS (Murashige \& Skoog, 1962), acrescido de sacarose (30 g. $\left.\mathrm{L}^{-1}\right)$, mio-inositol (100 mg. $\left.\mathrm{L}^{-1}\right)$, 6benzilaminopurina (BAP) $1 \mathrm{mg} . \mathrm{L}^{-1}$, ácido-naftalenoacético (ANA) 0,01 mg.L, ácido giberélico $\left(\mathrm{AG}_{3}\right) 1 \mathrm{mg} \cdot \mathrm{L}^{-1}$ e ágar (6 g.L $\mathrm{L}^{-1}$ ), sendo o pH ajustado a 5,9 com $\mathrm{NaOH}(1 \mathrm{~N})$ antes da adição do agente solidificante. Após a inoculação dos explantes no meio de cultura os frascos foram mantidos em sala de crescimento, por 45 dias, sob 16 horas de fotoperíodo, 2000 lux de intensidade luminosa e temperatura de $25^{\circ} \mathrm{C} \pm 2^{\circ} \mathrm{C}$.

A partir do desenvolvimento dos meristemas, em meio de cultura obteve-se brotações com 2 a $3 \mathrm{~cm}$ que foram divididas em segmentos caulinares contendo uma gema axilar e inoculadas em tubos de ensaio contendo $10 \mathrm{ml}$ de meio básico MS sem reguladores de crescimento e com todos os demais componentes da fase anterior. Os frascos foram mantidos em sala de incubação à temperatura e fotoperíodo idênticos aos utilizados no desenvolvimento de meristemas. Após quatro semanas originaram-se novas brotações de 10 a $12 \mathrm{~cm}$

Ao atingir o comprimento médio de $12 \mathrm{~cm}$, as brotações sadias (conforme teste de indexação realizados previamente) das duas cultivares foram divididas em segmentos caulinares de $2 \mathrm{~cm}$ de comprimento, contendo duas gemas axilares e inoculadas em meio MS acrescido de sacarose (10, 30 e 50 g. $\left.\mathrm{L}^{-1}\right)$; ácido acetilsalicílico $\left(0,3,6,9\right.$ e $\left.12 \mathrm{mg} \cdot \mathrm{L}^{-1}\right)$ e mantidas às temperaturas de $10 \mathrm{e} 25^{\circ} \mathrm{C}$.
O experimento constituiu-se de um fatorial $\mathrm{AxBxCxD}$ [temperatura (2) $\mathrm{x}$ sacarose (3) x AAS (5) x cultivar (2)], em blocos casualizados, com quatro repetições, sendo que cada explante representou uma parcela. Os dados referentes ao comprimento do segmento caulinar foram analisados utilizando-se o teste de Duncan e a regressão polinomial dos fatores. As avaliações foram iniciadas quinze dias após a instalação do experimento e continuadas a cada quinze dias, sucessivamente, ao longo de 180 dias. Da variável percentagem de sobrevivência do material em conservação in vitro foi apenas calculado o seu valor médio.

\section{RESULTADOS E DISCUSSÃO}

Os resultados da análise da variação apresentaram significância estatística para a grande maioria dos fatores e interações. Somente não foram significativas $(a=0,05)$ as interações AAS $x$ cultivar e temperatura $\mathrm{x}$ AAS $\mathrm{x}$ cultivar. Tendo em vista este fato e visando uma simplificação do trabalho, selecionamos apenas interações de primeira ordem que se apresentaram como altamente significativas $(a=0,01)$. Da variável percentagem de sobrevivência do material em conservação in vitro foi apenas calculado o seu valor médio.

A redução de temperatura proporcionou um menor crescimento dos segmentos caulinares para a cultivar Baronesa à temperatura de $10^{\circ} \mathrm{C}$ (Figura 1). Para $25^{\circ} \mathrm{C}$ ocorreu uma inversão de cresci-

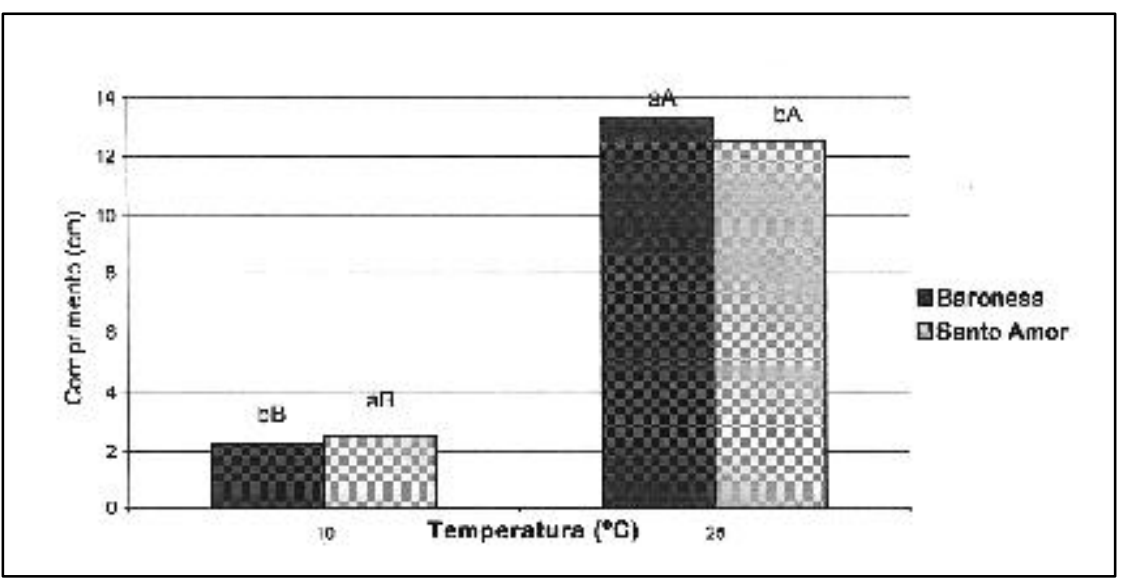

Figura 1. Comprimento de segmentos caulinares de batata cvs. Baronesa e Santo Amor à temperatura de 10 e $25^{\circ} \mathrm{C}$, após seis meses de conservação in vitro, Pelotas-RS, Embrapa Clima Temperado, 1997 (as letras minúsculas correspondem as comparações entre as cultivares, dentro de uma mesma temperatura e as letras maiúsculas indicam as comparações entre as temperaturas, para uma mesma cultivar, pelo teste de Duncan $(a=0.05))$. 


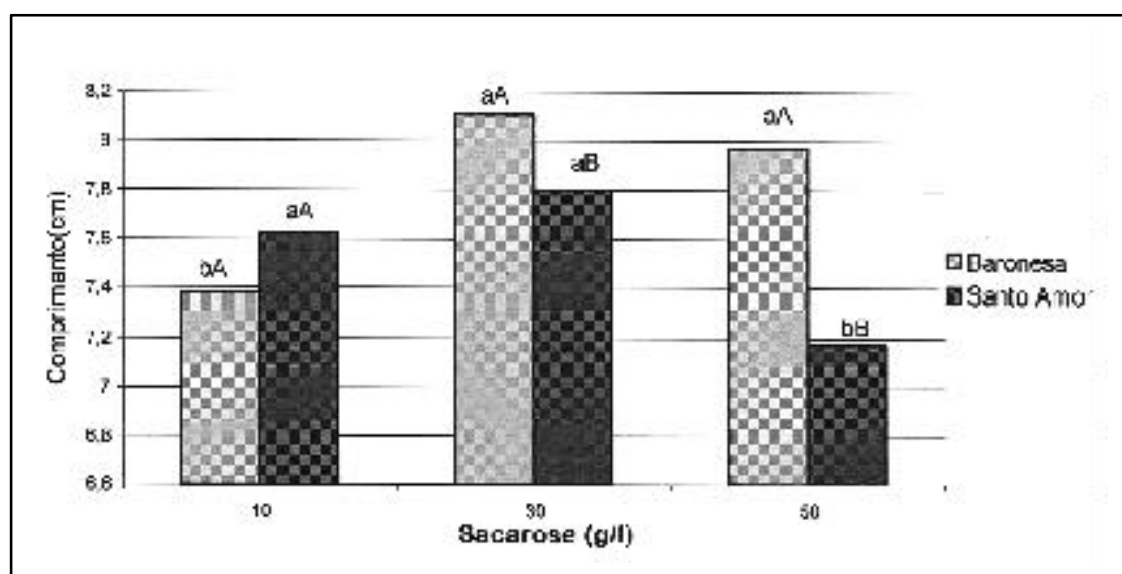

Figura 2. Comprimento dos segmentos caulinares de batata cvs. Baronesa e Santo Amor nas concentrações de 10,30 e $50 \mathrm{~g} / \mathrm{l}$ de sacarose, após seis meses de conservação in vitro, PelotasRS, Embrapa Clima Temperado, 1997 (as letras minúsculas correspondem as comparações entre as concentrações de sacarose para uma mesma cultivar e as letras maiúsculas indicam as comparações entre as cultivares, para uma mesma concentração, pelo teste Duncan $(a=0.05)$ ).

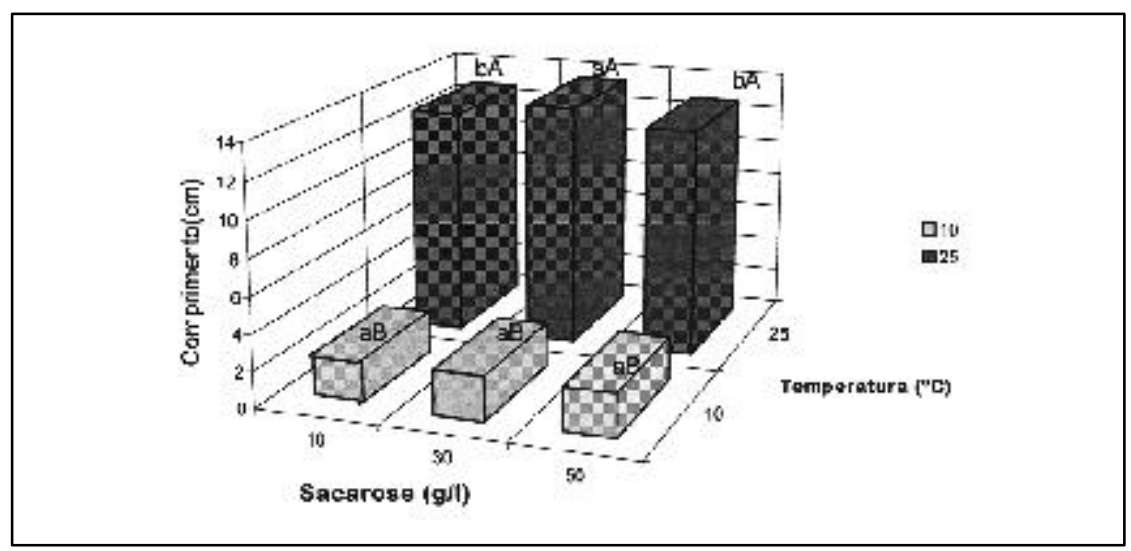

Figura 3. Comprimento de segmentos caulinares de batata para a média das cultivares às concentrações de 10,30 e $50 \mathrm{~g} / \mathrm{l}$ de sacarose, e sob temperatura de 10 e $25^{\circ} \mathrm{C}$, após seis meses de conservação in vitro, Pelotas-RS, Embrapa Clima Temperado, 1997 (as letras minúsculas correspondem às comparações entre as concentrações de sacarose dentro de uma mesma temperatura e as letras maiúsculas indicam as comparações entre as temperaturas, para uma mesma concentração de sacarose, pelo teste Duncan $(\mathrm{a}=0.05))$.

mento em relação às cultivares, sendo os segmentos caulinares da cultivar Baronesa os que mais cresceram. Isto pode ser atribuído a uma característica genotípica (Jabuonski \& Furumoto, 1987); a cv. Baronesa possui porte médio, e a cv. Santo Amor porte baixo, embora a Santo Amor seja proveniente do cruzamento entre as cultivares Baronesa e Konsuragis (Hawkes, 1978). À temperatura de $10^{\circ} \mathrm{C}$, ocorreu um crescimento lento dos segmentos caulinares de batata, provocado por uma desaceleração na velocidade do metabolismo celular, devido à baixa temperatura os processos metabólicos são mais lentos (Desbrunais et al. (1980), trabalhando com segmentos caulinares de genótipos de batata à temperatura de $6^{\circ} \mathrm{C}$ e $8 \mathrm{~h}$ de fotoperíodo à noite e de $12^{\circ} \mathrm{C}$ e $16 \mathrm{~h}$ de fotoperíodo durante o dia, obtiveram um índice de $80 \%$ de sobrevivência do material em seis meses de conservação in vitro.

As cultivares Baronesa e Santo Amor produziram 24 e 27 microtubérculos respectivamente, após 6 meses da conservação in vitro. Verificou-se que ocorreu um maior crescimento dos segmentos caulinares com o aumento do nível de sacarose, sendo que para o nível de 30 g.L. $\mathrm{L}^{-1}$ obteve-se o maior comprimento dos segmentos caulinares, principalmente para a cultivar Baronesa (Figura 2). A redução verificada quando se passa de 30 g. $\mathrm{L}^{-1}$ para 50 g. $\mathrm{L}^{-1}$ para a cultivar Santo Amor pode ser atribuída à formação de microtubérculos quando utilizada a concentração maior de sacarose no meio de cultura. Karssem et al. (1991), relatam que a formação de microtubérculos é conseguida pela alta concentração de açúcar no meio de cultura. Aumentando a concentração de sacarose de 2 a $8 \%$, houve um aumento de até $100 \%$ na formação de microtubérculos em estacas nodais com concomitante redução no elongamento do estolão.

Segmentos caulinares à temperatura de $25^{\circ} \mathrm{C}$ apresentaram um maior comprimento, do que aqueles a $10^{\circ} \mathrm{C}$ em todas as concentrações de sacarose, sendo que a concentração de 30 g.L. $\mathrm{L}^{-1}$ foi superior às demais. A temperatura de $25^{\circ} \mathrm{C}$ proporciona um aumento na velocidade do metabolismo celular e, consequentemente, um maior crescimento dos segmentos caulinares (Figura 3). Resultados similares foram obtidos por Desbrunais et al. (1992) conservando segmentos caulinares de café in vitro à temperatura de $27^{\circ} \mathrm{C}$ com 20g. $\mathrm{L}^{-1}$ de sacarose.

Com o aumento da concentração de AAS em meios de cultura submetidos à temperatura de $25^{\circ} \mathrm{C}$, ocorreu redução no crescimento médio dos segmentos caulinares das distintas cultivares (Figura 4). Os retardantes de crescimento reduzirem o elongamento das hastes (Gianfagna, 1987). A temperatura de $10^{\circ} \mathrm{C}$, quando comparada com a de $25^{\circ} \mathrm{C}$, foi mais eficiente na redução do crescimento dos segmentos caulinares, mesmo na ausência de AAS. Entretanto, segundo Grout (1991), retardantes de 
crescimento devem ser adicionados ao meio de cultura e a temperatura deve ser reduzida entre 1 e $10^{\circ} \mathrm{C}$, para promover uma redução na velocidade de crescimento do material em conservação.

Com respeito à percentagem de sobrevivência dos segmentos caulinares em conservação in vitro, obteve-se maior percentual de sobrevivência a $10^{\circ} \mathrm{C}$, atingindo cerca de $87 \%$, para a média das cultivares. À temperatura de $25^{\circ} \mathrm{C}$, ocorreu um maior percentual de perda de material atingindo aos seis meses de conservação, com aproximadamente $57 \%$ de sobrevivência. Estas perdas foram atribuídas à contaminação por microorganismos, pois com o aumento da temperatura há uma maior condensação de água no frasco, favorecendo o desenvolvimento de fungos. Resultados semelhantes foram obtidos em estudos sobre a conservação in vitro de gemas de macieira, onde ocorreu perda do material à temperatura de $26^{\circ} \mathrm{C}$, devido à contaminação por microorganismos e à diminuição do meio de cultura. (Lundergan \& Janick, 1979). Estes resultados com as cultivares Baronesa e Santo Amor superaram os obtidos por Fortes et al. (1995), que obtiveram quatro meses e meio de conservação in vitro para segmentos caulinares das cultivares Baronesa e Monte Bonito.

Os resultados obtidos neste trabalho, sugerem que a melhor conservação in vitro e a maior percentagem de sobrevivência dos segmentos caulinares de batata foram obtidos com a concentração de 30 g.L. $\mathrm{L}^{-1}$ de sacarose no meio de cultura e à temperatura de $10^{\circ} \mathrm{C}$.

\section{AGRADECIMENTOS}

Os autores agradecem à Embrapa Clima Temperado, pelo uso das instalações para execução do ensaio e também ao $\mathrm{CNPq}$ pelos recursos fornecidos.

\section{LITERATURA CITADA}

BHAT, S.R., CHANDEL; K.P.S. In Vitro Conservation of Musa Germplasm: Effects of Manitol and Temperature on Growth and Storage. Journal of Horticultural Science, v. 6, p. 841-846, 1993.

CARSWELL, G.C.; JOOHNSON, R.D.; HARMA, C.T. O-acetyl-salicilyc acid promotes colony formation from protoplasts of an elite maize inbred. Plant Cell Reports, v. 8, p. 282-284, 1989.

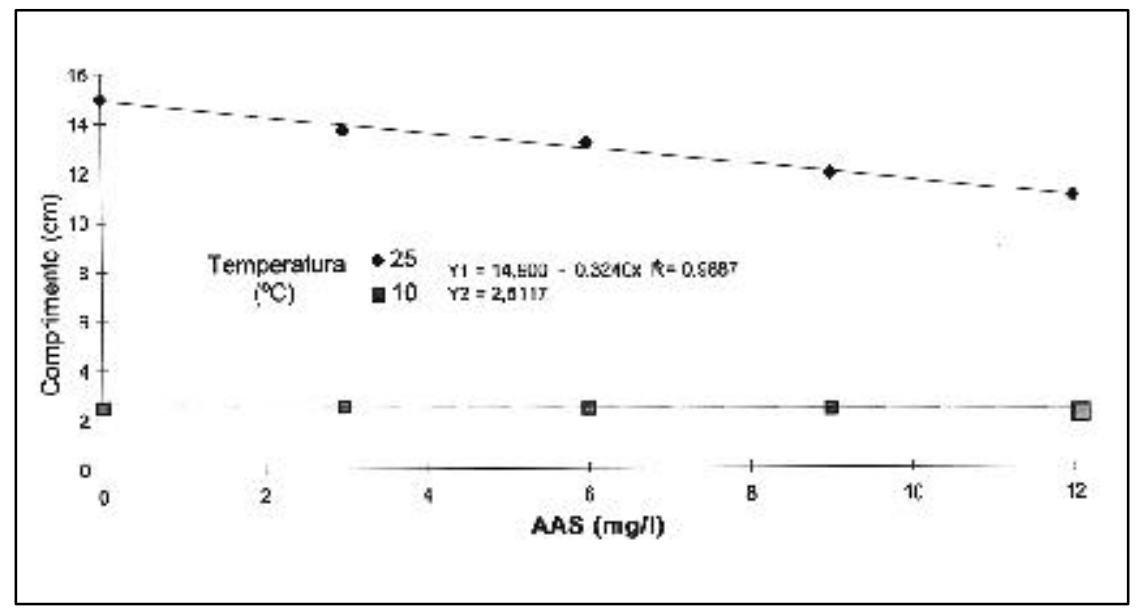

Figura 4. Comprimento de segmentos caulinares de batata para a média das cultivares às concentrações de $0,3,6$, 9, e $12 \mathrm{mg} / \mathrm{l}$ de AAS, e temperatura de 10 e $25^{\circ} \mathrm{C}$, após seis meses de conservação in vitro, Pelotas-RS, Embrapa Clima Temperado, 1997.

DESBRUNAIS, B.A; NOIROT, M. CHARRIER, A. Slow growth in vitro conservation of coffee (Coffea spp.). Plant Cell Tissue and Organ Culture, v. 31, p. 105-110, 1992.

DORION, N.; KADRI, M.; BIGOT, C. In vitro preservation at low temperature of rose plantlets usable for direct acclimatization. Acta Horticulturae, v. 298, p. 335-343, 1991.

FORTES, G.R. de L.; LEITE, D.L.; MAGALHÃES, Junior., A.M. Conservação in vitro de alho (Allium sativum); aspargo (Asparagus oficinallis) e batata (Solanum tuberosum L.). In: REUNIÃO ESTADUAL DE BIOTECNOLOGIA VEGETAL, 8, Pelotas, 1995, p. 30.

GIANFAGNA, T. J. Natural and Synthetic Growth Regulators and Their use in Horticultural and Agronomic Crops. In: Plant Hormones and Their Role in Plant Growth and Development. DAVIES, P.J. (Ed.), London, 1987 p. 626-632.

GROUT, B.W.W. Conservation in vitro. Acta Horticulturae, v. 289, p. 171-178, 1991.

HAWKES, J.G. History of the potato. In: HARRIS, P.M. The Potato Crop: The scientific basis of improvement.London, Chapman and Hall, p. 1-14, 1978.

HENSHAW, G.G.; HARA, J.FO.; WESTCOTT, R.J. Tissue culture methods for the storage and utilization of potato germplasm. In: INGRAM, D.S.; HELGESON, J.P. Tissue culture methods for plant pathologists. Boston: Blackwell, 1980, p. 71-76.

IBGE, Anuário Estatístico Brasileiro, v. 57, p. 341, 1997.

JABUONSKI, R.E.; FURUMOTO, O. Características das cultivares. In: Produção de Batata. REIFSCHNEIDER, F.J.B. (Coord). Brasília, 1987, p. 6-11.

KAIHARA, S.; WATANABE, K.; TAKIMOTO, A. Flower-inducing effect of benzoic and salicylic acids on various strains of Lenna paucicostata and L. Minor. Plant Cell Physiology, v. 22, p. 819-825, 1981.

KARSSEM, C M.; VFANLOON, L.C.; VREUGDENHIL, D. Hormonal and metabolic control of tuber formation: Current Plant Science and Biotechnology in Agriculture. Kluwer Academic Publishers, p. 393-400, 1991.
KHUARAMA, J.; MAHESWARI, S. Induction of loweing in Lenna paucicostata by salicylic acid. Plant Science Letters, v. 12, p. 127-131, 1978.

LARQUE-SAAVENDRA, A. Stomatal closure in response to acetylsalicylic acid treatment. Zeitschrift der Pflanzenphysiology, v. 93, p. 371-375, 1979.

LEITE, D.L.; FORTES, G.R. de L.; GARCIA, A; WINKLER, L.M. Conservação in vitro de alho (Allium sativum L.) cv. Quitéria. In: ENCUENTRO LATINO AMERICANO DE BIOTECNOLOGIA VEGETAL 2, Puerto Iguazu, Argentina, 1995, A-67p.

LESLIE, C.A.; ROMANI, R.J. Inhibition of ethylene biosynthesis by salicylic acid. Plant Physiology, v. 88, p. 833-837, 1988.

LUNDERGAN, C.; JANICK, J. Low temperature storage of in vitro apple shoots: HortScience, v. 88,1979 , p. $833-837$.

MILLS, P.R.; WOOD, R.K.S. The effects of polyacrylic acid, acetylsalicilic acid and salicylic acid on resistance of cucumber to Colletotrichum lagenarium. Phytopathology Zeitschrift, v. 111, p. 209-216, 1984.

MURASHIGE, T.; SKOOG, F.A revised medium for rapid growth and bioassays with tobacco tissue culture. Physiologia Plantarum, v. 15, p. 473-497, 1962

OHASHI, Y.; MATSUOKA, M. Induction and secretion of pathogenesis-related proteins by salicylate or plant hormones in tobacco suspension cultures. Plant Cell Physiology, v. 28, p. 573-580, 1987.

ROCA, W.M.; ARIAS, D.I.; CHAVES, R. Metodos de Conservacion in vitro del Germplasma. In: ROCA, W.M.; MIOGINSKI, L.A. Cultivos de Tejidos en la Agricultura, Cali, 1991, p. 697-714.

SALISBURY, F.B.; ROSS, C.W. Plant Physiology, Wadsworth Publishing Company, California, 1992, 400p.

SHARMA, N.; CHANDEL, K.P.S. Low Temperature Storage of Raulfovia serpentina Benth. Ex Kurg and Endangered Endemic Medicinal Plant. Plant Cell Reports, New York, v. 11, p. 200-203, 1992.

WITHERS, L.A.; WILLIAMS, J.T. Germplasm Conservation in vitro and Cryopresevation. In: TORRES, A.C., CALDAS, L.S. Técnicas e aplicações da cultura de tecidos de plantas. Brasília: ABCTP/EMBRAPA-CNPH, 1990, p. 267-286. 